\title{
Public health leadership in the times of COVID-19: a comparative case study of three countries
}

\author{
Jeffrey Glenn \\ Brigham Young University, Provo, Utah, USA \\ Claire Chaumont \\ Harvard T H Chan School of Public Health, Harvard University, \\ Boston, Massachusetts, USA, and \\ Pablo Villalobos Dintrans \\ Programa Centro Salud Pública, Facultad de Ciencias Médicas, \\ Universidad de Santiago de Chile, Santiago, Chile
}

\begin{abstract}
Purpose - The purpose is to understand the role of public leadership during the COVID-19 pandemic and advocate for a more active role of public health professionals in helping manage the crisis.

Design/methodology/approach - The authors use the framework developed by Boin et al. (2005) on crisis leadership. The authors focus on three of the core tasks - sense-making, decision-making and meaning-making - that are relevant to explain the role of public leaders during the ongoing crisis. The authors draw from the experience of three countries - Chile, France and the United States - to illustrate how these tasks were exercised with concrete examples.

Findings - Several examples of the way in which public leaders reacted to the crisis are found in the selected countries. Countries show different responses to the way they assessed and reacted to the COVID-19 as a crisis, the decisions taken to prevent infections and mitigate consequences, and the way they communicate information to the population.

Practical implications - A better understanding public leadership as a key for better crisis management, particularly for designing policy responses to public health crises. Public health leaders need to assume a more active role in the crisis management process, which also implies the emergence of a new class of public health leaders and a more prominent role for public health in the public eye.

Originality/value - The use of examples from three different countries, as well as the focus on the core leadership tasks during an ongoing crisis help not only assessing the crisis management but also extracting lessons for the coming months, as well as future public health emergencies. The three authors have a first-hand experience on the evolution of the crisis in their countries and the environment, since they are currently living and working in public health in Chile, France and the United States.
\end{abstract}

Keywords Comparative analysis, Decision making, Leadership roles, Public leadership, Public health,

Emergency management

Paper type Viewpoint

\section{Introduction}

Public leaders on every continent are currently facing a public health crisis on a scale that has not been seen since the Spanish Flu pandemic over 100 years ago. On December 31, 2019, Chinese authorities informed the World Health Organization (WHO) about an outbreak of an unknown respiratory disease. On January 30, 2020 the WHO declared the outbreak of COVID-19 as a public health emergency of international concern. Cases extended quickly from the city of Wuhan to other parts of China and, since then, to the whole world (World Health Organization, 2020a). Since December 31, 2019, when the first case was reported to the WHO by Chinese authorities, close to 30 million cases have been confirmed in 216 countries, with more than 930,000 deaths (World Health Organization, 2020b).

The authors thank the comments and suggestions from two anonymous reviewers and the editor.
Public health leadership in times of COVID

Received 28 August 2020 Revised 29 September 2020 Accepted 17 October 2020 
IJPL 17,1

With advances in science and technology, huge improvements in population's life expectancy and health systems, and a relatively long period of global peace and political stability, COVID-19 emerges as an unexpected threat to many things we took for granted. The new coronavirus has raised several questions, not only regarding the virus itself, but also about how different countries' leaders responded to the pandemic. Looking back and thinking forward, we all ask whether leaders could have done something differently to better deal with the disease.

In this context, managing the COVID-19 crisis highlights the critical need for effective public leadership, a form of collective leadership in which public bodies and agencies collaborate to generate public value for the common good (Brookes, 2011; Getha-Taylor et al., 2011). While some scholars focus on a narrow definition of public leaders as administrative officials that manage government and non-profit agencies (Van Wart, 2013; Vogel et al., 2020), a broader view also includes elected political leaders (Ospina, 2017). Among the many competing demands public leaders face, two that are commonly highlighted in the literature are the tension between political responsiveness and administrative responsibility as well as the changing nature of leadership roles amidst increasing cross-sectoral collaboration (Kirlin, 1996; Jung et al., 2008; Vogel and Masal, 2015).

Crises always present complex leadership challenges for people in positions of authority (Boin and 't Hart, 2003). Public leaders are expected to play several roles, including understanding and adapting to the problem, as well as planning and implementing solutions to restore normalcy (Jong, 2017; Vogel and Masal, 2015). While principles of good crisis leadership echo those of non-crisis leadership in many respects, the need for decisive, hierarchical leadership is heightened in crisis situations whereas transformational leadership and network governance are typically considered to be more important in the operation of routine public sector organizations (Brookes, 2011; Kapucu and Van Wart, 2008; Vogel and Masal, 2015). However, the more "wicked" the problem (compared to critical or tame problems) the greater the need for progressive or distributed leadership that incorporates the perspectives of multiple stakeholders (O'Reilly et al., 2015; Tilley, 2010). Public leaders are also expected to communicate with their people (Jong, 2017). Effective communication is essential to ensuring that authorities are perceived as leaders as they act within their roles to manage the crisis (Brookes, 2011). Building the capability and capacity of public leaders is considered a critical success factor to handling public crises (Brookes, 2011).

The current COVID-19 situation shares similarities with other types of crises, but it also differs in several important aspects. First, this is a public health crisis, which requires a different type of specific technical knowledge and experience from many other recent crises (Deitchman, 2013). Second, unlike other public health crises this is different not just in terms of its consequences, and countries' capacities to foresee this event, but also its scale (Hannah et al., 2009). As a global problem, COVID-19 poses the same (meta) problem to different countries with different contexts. Finally, this crisis intermingles health, social and economic aspects in a way rarely seen before during modern disease outbreaks.

Given this scenario, our primary research questions ask where breakdowns in public leadership have occurred during the COVID-19 response and whether public health leadership could have played a different role in managing the crisis. In the section on lessons and recommendations we consider how we can encourage this type of leadership in the future and, in particular, what role public health leaders - i.e. individuals that have vision, influence and competencies regarding public health issues (Ypahntides et al., 2015) - should play in public health crises.

This article analyzes the COVID-19 experience of three countries: Chile, France, and the United States (US), which each tells a different story about leadership. We selected these countries as concrete examples of the public leadership response to COVID-19. The selection was based on the principles of comparative studies, focusing on the scope of the analysis 
(leadership response), outcome of interest (three of the most affected countries in the world), and diversity of settings (distinctive geographical areas, demographic profiles, and economic, social and cultural differences) which play an important role in shaping the context in which public leaders act and in determining the feasibility of competing policy alternatives (Lijphart, 1971; Yin, 2014). Differences in political institutions, health system design, and beliefs about the role of public health are additional important factors that influence public leadership approaches to managing the pandemic. As Table 1 shows, in terms of the COVID19 situation, the three countries also present interesting differences: the pandemic reached the US and France almost a month before the first case was identified in Chile and the countries exhibit different outcomes in terms of cases. (Johns Hopkins University, 2020).

All these differences constitute an opportunity, allowing us to analyze the exercise of public leadership under a single problem in different contexts, as a way to highlight differences but also similarities in crisis leadership challenges across countries. While inferring direct causal relationships between leadership approaches and country outcomes is beyond the scope of this case analysis due to the complexity of the pandemic, using rigorous methods to assess the effectiveness of public leaders' COVID-19 response-related decisions represents an important area for future research.

\section{A framework to understand leadership in crisis}

We draw on our experience and observations as public health researchers and practitioners in these three countries to address our research questions. While we have acknowledged some of the other important work on crisis leadership above, we have chosen to conduct our analysis using the framework developed by Boin et al. (2005) about the five core tasks of crisis leadership. We find this framework to be particularly insightful in allowing us to compare and contrast critical elements of the COVID-19 response across countries. According to Boin et al., the public's expectations of government authority figures to make critical decisions and provide direction during times of crisis create unique governance challenges with real political consequences (p. 8). Rather than focusing on a person-related perspective of crisis leadership, the model defines leadership as a "set of strategic tasks that encompass all activities associated with the stages of crisis management" (p. 9). Boin and colleagues identify five core tasks of leadership during crises: sense making, decision making, meaning making, crisis termination, and learning.

First, sense making involves leaders' attempts to recognize that a crisis exists and to understand what is happening and why as events unfold in real time. This task presents a number of significant leadership challenges. Public organizations are usually ill-designed to quickly identify and respond to threats, and when they do, it is typical for crucial information to become subject to intra- and inter-organizational politics (pp. 20-22). Stress associated with professional (and personal) responsibilities is amplified during a crisis and may have serious consequences for the performance of decision makers (p. 29). Additional individual constraints - such as cognitive heuristics and biases, egocentric motives, and affiliations

\begin{tabular}{lclcccc}
\hline Country & $\begin{array}{c}\text { Pop. } \\
\text { (Millions) }\end{array}$ & $\begin{array}{l}\text { Starting date } \\
\text { (WHO report) }\end{array}$ & $\begin{array}{c}\text { Cumulative } \\
\text { cases }\end{array}$ & $\begin{array}{c}\text { Cases per } \\
1,000 \\
\text { people }\end{array}$ & $\begin{array}{c}\text { Cumulative } \\
\text { deaths }\end{array}$ & $\begin{array}{c}\text { Deaths per } \\
1,000 \text { people }\end{array}$ \\
\hline Chile & 19.1 & March 3 & 376,616 & 19.72 & 10,178 & 0.53 \\
France & 65.3 & January 24 & 189,972 & 2.91 & 30,214 & 0.46 \\
United & 331.0 & January 20 & $5,039,709$ & 15.23 & 162,104 & 0.49 \\
States & & & & & &
\end{tabular}

Source(s): World Health Organization (2020b)

Public health leadership in times of COVID

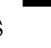


IJPL

17,1

84

to particular groups or values - affect leaders' capacity for processing large amounts of data (pp. 31-33).

Second, decision making involves evaluating alternatives, making critical choices, and coordinating the response network in the face of uncertainty and political risks. Group dynamics among the various stakeholders involved in a crisis response make this task inherently difficult; some groups tend towards excessive cordiality and conformity while other groups are paralyzed by conflict and politicking (pp. 46-48). Since critical decisions are often required across a range of policymakers and small groups, factors such as decentralization, interorganizational relations and improvisation are critical for the decision making task (pp. 52-55). Rather than acting as all-powerful decision makers, effective leaders should consider themselves as designers and facilitators of a robust coordination process (p. 64).

Meaning making considers crisis management as political communication and involves leaders' attempts to influence the public's understanding of the crisis. The challenge in this task comes from communicating a persuasive narrative in a context of overwhelming amounts of information and uncertainty, all while maintaining credibility and building trust (p. 78). Leaders who succeed may find a greater degree of permissive consensus to enact their policies while leaders who fail often fall into a vicious cycle of distrust breeding lower credibility (p. 81). Barriers to effective crisis communication include coordination of outgoing information between government entities, tension between political and administrative messengers, and communicating clearly in the context of mediated messages (pp. 77-78). Carefully framing messages, staying attentive to public "rituals," and avoiding unnecessary masking of facts are critical factors to maintaining leaders' credibility (pp. 81-87).

The final two tasks focus on the end stage of a crisis and on preparation for future crises. Terminating is about leaders' efforts to return to normalcy and involves shifting away from emergency operations as well as reconciling with the issue of accountability in order for governance to be restabilized. Successful crisis termination depends largely on accountability processes perceived as legitimate by the population. Finally, learning involves drawing political and organizational lessons to plan and train for future crises. Despite the widespread belief that crises are opportunities for reform, Boin et al. argue that leaders should avoid focusing on large-scale change as part of the learning task.

Since the COVID-19 crisis is still ongoing, our analysis focuses only on the first three critical tasks. While current leadership actions clearly influence how the crisis will be terminated and how lessons will be learned for future crises, analysis of these tasks is best reserved for subsequent research. Using the first three core tasks, we extracted examples for each of the selected countries, to illustrate the way in which leadership was exercised regarding the management of the COVID-19 crisis, particularly by public health leaders, but also by political and administrative leaders. Concrete examples are extracted from news and reports in each one of the countries.

\section{Leadership exercise in Chile, France and the US}

We summarized examples for three core tasks in the three countries using the categories presented in Table 2.

Table 2.

Boin et al. (2005) selected core tasks and themes arising from the examples

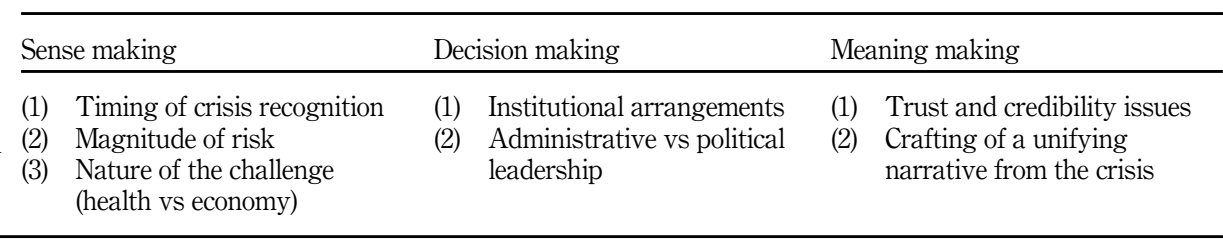


Sense-making: acknowledging a public health crisis

Different attitudes with regards to sense-making have been observed across the three countries at the beginning of the COVID-19 crisis. As Boin mentioned, leaders are often caught in a cross-fire between conflicting directives: do nothing and risk tragedy or do too much and risk mockery. Overall, the ability of leaders to accurately detect early warnings of the crisis and appropriately warn the public about the threat level was essential in how they later managed (or mismanaged) it.

An important element has been the ability of leaders to recognize the crisis quickly. While delays occurred in all three countries, this denial was most marked in the US, where political leaders at the national and, in many cases, the state levels were slow to acknowledge that the virus presented real and severe risks to the country (The Atlantic, 2020). In contrast, previous outbreaks in the US have often received more rapid attention from national leaders. For example, President Barack Obama was largely praised for his administration's relatively quick action to address the 2009 H1N1 swine flu pandemic, and President Gerald Ford was even criticized for overreacting by responding too quickly with what turned out to be an ineffective and unsafe vaccine during the 1976 swine flu outbreak (Discover Magazine, 2020; The Washington Post, 2020a). A contributing factor to the slow COVID-19 response was the lack of preparedness, as evidenced by the Trump administration's efforts early in his presidency to reduce the pandemic preparedness budget and disband the government team responsible for protecting the country from biological threats (Slate, 2020). In France, authorities acknowledged the severity of the virus, but were slow to recognize it as a domestic crisis: while cases were found as early January 24 in France, they were all linked to international travels, leaving French authorities to believe the epidemic was under control (Dautriche, 2020). Finally, Chile officially recognized the problem in early February (phase 1), moving quickly into the next step after the announcement of the first case, the first week of March (Villalobos Dintrans et al., 2020).

In addition to the speed of response, an important dimension in sense making relates to the assessment of the risks and responses to the crisis (Maor, 2014). In the case of Chile, there was an explicit recognition of the magnitude and importance of the problem but an excess of confidence in the country's capacities to face the challenge (Barlett, 2020; Mella, 2020). For example, immediately after declaring a state of constitutional exception due to the national catastrophe, President Piñera declared that "Chile is better prepared than Italy to face this situation" (Cerda, 2020). In contrast, although France was quick to acknowledge the public health danger it faced, authorities still struggled to balance public health measures with other priorities, despite warnings from their Italian counterparts (France Television, 2020). For example, the government maintained the organization of nation-wide elections as late as midMarch following recommendations from the scientific committee, citing concerns over how an interruption of the democratic process could be perceived by the population (Elysee, 2020; Philippe, 2020; Conseil Scientifique COVID-19, 2020). Overall, the US acknowledgement of the severity of the risk continued to lag behind the rest of the world. Even while authorities in the regions affected early, such as New York City and Seattle, mobilized to curb the virus' spread and "flatten the curve" to avoid overwhelming hospitals, President Trump insisted over 27 times that the virus would "simply go away" (Bump, 2020).

How the crisis was interpreted, a process that begins in the sense making task but heavily influences leadership decision making, also differed across countries. In the US, a narrative quickly emerged that leaders faced a binary choice between addressing the health crisis or saving the economy (Forbes 2020; McKee and Stuckler, 2020). After initial state lockdowns contributed to skyrocketing unemployment rates and fears about a major economic recession, political leaders across the country, often divided along partisan lines, argued over whether the economic effects of the shutdowns were worse than the disease itself (The Conversation, 2020). One notorious example occurred when the Lieutenant Governor of
Public health leadership in times of COVID 
IJPL

17,1

86

Texas said during a national television interview that he and other senior citizens would be willing to die to save the economy for their grandchildren (NBC News, 2020). While many experts correctly recognized the inherent inseparability of the health and economic issues, the false dichotomy that was initially widely accepted impeded efforts to make good public policy that could balance the health and economic needs of the country. A similar tension was observed in Chile, where national and local authorities debated about whether the country was "flattening the curve" and already reached the "peak"; the uncertain interpretation of the data encouraged a allegedly trade-off between health and economy. While on one hand, several mayors were demanding the government for applying quarantines in their counties, an open debate on the number of recoveries and the need to reopen the economy was installed. A failed attempt to open a shopping center occurred in May, and the same debate has been going on since July, when cases started to decrease (La Tercera, 2020). While concerns over an economic turmoil were equally strong in France, this trade-off narrative was less present. In its address to the country on March 12, 2020, President Macron underlined that lives should be saved "regardless of the price" (France Info, 2020). The government also quickly adjusted its legislation to support companies and prevent massive layoffs, in the hope it would help the economy recover faster (Ministere de l'Economie, des Finances et de la Relance, 2020). The impact of the crisis was also framed differently: interestingly, while data in the US quickly emerged to show how the virus disproportionately affected specific populations, such a focus on inequity was almost nonexistent in the French public discourse (Fassin, 2020).

\section{Decision making: institutions and the tension between administrative and political leadership}

Decision-making processes during the COVID-19 crisis have also been very different across countries and led to very different outcomes. First, governments were forced to create $a d-h o c$ responses as existing risk management processes were insufficient considering the scale and uniqueness of the situation. In these responses, existing processes and institutional structures played a big role (Nyenswah et al., 2016). For example, in the US, the complexity of its institutional system, with states yielding important powers, led to a disjointed response with each state government making its own decisions about imposing lockdown rules. While this arrangement allowed states to tailor their responses to local circumstances, it also led to a wide range of responses that varied greatly in terms of effectiveness due to variability in leadership decision making and public health capacity, which resulted in huge differences in morbidity and mortality across states. On the other end of the spectrum, France, a very centralized country, imposed a strict lockdown even in regions with no reported cases (Hale et al., 2020). Chile also opted for a centralized management, with all the information and decision-making process hosted at the central level, coordinated by the Ministry of Health (Ministerio de Salud, 2020). The country used a dynamic-quarantine approach, in which specific geographic areas were put in and out of lockdown on a weekly basis (Villalobos Dintrans et al., 2020). The strategy was said to be the most common one implemented around the world (CNN-Chile, 2020a).

Another important factor to contrast is the role of administrative vs. political leaders in this crisis. Public administrators, especially those selected for their scientific or technical expertises, such as public health administrators, have played very different roles in the three countries. In the US, the tensions between public administrators and politicians have seriously inhibited response efforts. At the federal level, President Donald Trump publicly disagreed on numerous occasions with Dr. Anthony Fauci, one of the world's leading infectious disease experts and the face of the President's own Coronavirus Task Force, about various key facts about the scientific features of COVID-19 (Yahoo News, 2020). There has also been public tension between the President and the Centers for disease Control and 
Prevention (CDC), the federal government's lead scientific public health agency, about issues related to data reporting, guidelines for school reopenings, and testing of asymptomatic individuals (New York Times, 2020; NPR, 2020a; The Washington Post, 2020b). These and similar disputes at state and local levels have led to public confusion and the rapid spread of disinformation that have undermined public health messages and made it harder for a unified strategy around key decisions (Lancet Infectious Diseases, 2020; Scientific American, 2020). By contrast, in France and Chile, technical experts have been used by political leaders to legitimize their decisions, through the creation of a scientific committee guiding the government's decisions, even though this committee has remained advisory in the case of France (Cooperativa, 2020a; Ministère des Solidarités et de la Santé, 2020). One notable example draws a stark contrast between how national leaders in France and the US have sought guidance from reliable scientific experts. After French microbiologist Didier Raoult gained worldwide notoriety for promoting the malaria drug hydroxychloroquine as a cure for COVID-19, despite questionable scientific methods, his views were criticized by French authorities, which forbid its use for COVID-19 patients while they were being elevated and used to guide policy by President Trump in the US (Esquire 2020).

\section{Meaning-making: trust and narratives}

Finally, leaders in each country have struggled to communicate a cohesive narrative around the unfolding crisis while attempting to maintain credibility and public trust. Trust is a critical antecedent to government legitimacy, which shapes citizens' responses to government demands (Brookes, 2011; Levi et al., 2009). The evidence that citizens who perceive their public leaders as trustworthy are more likely to comply with government demands is particularly relevant to the COVID-19 crisis because an effective response depends on collective compliance of public health guidelines (Devine et al., 2020; Levi and Stoker, 2000; Van Bavel et al., 2020). Previous pandemics have demonstrated the essential role that crisis communication plays in building trust and solidifying the perceived legitimacy of public leaders (Siegrist and Zingg, 2014). In Chile, effective communication has been an issue during the pandemic. The government faced the COVID-19 crisis with a very low approval rating, after the social outbreak that started in October 2019, and discontent could even increase with the management of the virus (Bossert and Villalobos Dintrans, 2020). Trust issues were exacerbated during the following months, mainly due to problems with the communication and interpretation of the data. These include the controversy regarding the "recovered" people (the government classifying as "recovered" all people without symptoms after 14 days and issuing an "immunity credential") and the number of deaths in the country (different figures in different reports), that ended with the resignation of the Minister of Health, Jaime Mañalich, on June 14 (Cooperativa 2020b; BBC, 2020; Sepúlveda, 2020). In the US, the public health crisis has further deepened the divide between political parties as trust and credibility appear to be starkly divided along ideological lines (Pew Research Center, 2020). With upcoming elections in November, President Trump and his Republican Allies have been accused by many of deliberately politicizing the crisis for political gain (The Nation, 2020). While this appears to have worked to achieve the goal of mobilizing political support, these actions have undermined public health efforts to stop the virus and have contributed to the comparatively poor US response compared to other countries (NPR, 2020b). This has been exacerbated by the tension between politicians and public administrators discussed above as some have placed complete trust in political leaders and dismissing scientific evidence while others have done the opposite. Finally, in France, the crisis has been used by various factions to push wider political agendas. Politicians and intellectuals have explicitly linked the public health crisis with the wider capitalistic system (Artus, 2020; Mestre and Zappi, 2020). The French government has also used the crisis to revive the unity
Public health leadership in times of COVID 
IJPL 17,1 of the European Union for example through the launch of the French-German initiative for the European recovery from the coronavirus crisis (Ministère des Affaires Etrangères, 2020).

The emergence of different public "rituals" further reveals leaders' attempts to influence public narratives around the crisis. In France, healthcare workers were designated as "heroes," a move widely seen as an attempt to divert the public attention from the strong social tension around healthcare reforms pre-crisis. For example, the government gave a medal to thank all healthcare workers for their engagement in the crisis (Telo, 2020). A similar situation was seen in Chile, with several days in which the authorities asked the people for "applauses" at night to pay homage to the healthcare workers (Andrews, 2020); the Congress were further, proposing a monetary allowance for health workers, arguing that "they deserve more than applauses" (CNN-Chile, 2020b). While healthcare workers (as well as teachers, grocers, and other "essential" workers) in the US have also been widely lauded by many for their efforts, a perceived lack of empathy from top political leaders for the extreme hardship faced by individuals affected by COVID-19 or its economic effects has made it challenging to craft a unifying narrative. For example, Senator Ted Cruz responded to Democrats' calls for increased financial support for suffering families by sarcastically tweeting "We have a magic money tree; we should use it!" (Bikales, 2020).

\section{Lessons and recommendations}

This article enhances Boin et al.'s crisis management framework by demonstrating how the framework can be operationalized in an ongoing global public health crisis across different contexts. Outbreak management measures, including mechanisms such as contact tracing or quarantine, are not new to public health professionals. But by its sheer scope, the current crisis has projected these routine public health policies into a new dimension: public health has been placed at the center of the public arena. This has positioned public health professionals not just as actors within their own discipline, but as leaders in a much broader context.

As shown by the three examples of Chile, France and the US, this did not come without frictions: in many cases, public health professionals struggled to provide or impose their leadership around sense-making, decision-making and meaning-making of the crisis, while at the same time, other political or administrative leaders attempted to use the public health crisis for other goals. The stories of the three countries give us important lessons to improve crisis management of the COVID-19 and other future public health issues.

First, it highlights the importance of better understanding public leadership as a key for better crisis management (Crosby and Bryson, 2018). In this article we explored three dimensions of this relationship - sense-making, decision-making and meaning-making showing how they can be used to explain some of the observed outcomes. This is not interesting just for showing what could have been done ex-post but to anticipate and design policy responses ex ante.

Second, it emphasized the role not just of public leaders but public health leaders in managing the COVID-19 crisis. Public health has been in the spotlight for several months, which poses a new dilemma for the profession: while public health professionals usually draw their legitimacy from the scientific process (in other words, their authority is based on their ability to draw upon scientific evidence), the COVID-19 crisis forced them to endorse a political role, for which truth is often a much more relative concept. Public health professionals were in many cases ill-prepared to endorse this role. As the crisis unfolded, this tension became evident: as scientific evidence was uncertain, health professionals struggled to communicate the sense and meaning of the events. Moreover, they often failed to fully participate in crisis management processes, often not designed to meaningfully capture their inputs, or were overshadowed by other figures more skilled in the political process. Finally, 
their narrow expertise sometimes limited their capacity to fully assess the social, economic or political consequences of the crisis, which in turn limited their ability to influence decisions made.

Unfortunately, the current crisis is far from over. But some important lessons can already be drawn from this experience, particularly around public health leadership. First, the scope of public health itself may need to be renegotiated. Health in All Policies approaches (Puska, 2007), which aim to push public health professionals to better engage with sectors outside the traditional healthcare sector which either directly impact or are impacted by public health phenomena, may become more prominent within the public health field. Second, public health professionals themselves may need to find a new balance between administrative and political power. This may require learning how to deal with the ambiguities that come with more political roles, while still promoting evidence-based decision-making (Deitchman, 2013). Third, this may require not just the emergence of a new class of public health leaders but also a more prominent role for public health in the public eye (Gray, 2009; Moodie, 2016). Public health differs from medicine because it focuses on the population level rather than the individual level. Nevertheless, due in part to a lack of understanding about the definition and value of public health, medical doctors have played a prominent role in this crisis, often at the expense of public health professionals specifically trained to apply this broad population lens to crises such as the one we are experiencing.

\section{Conclusion}

The COVID-19 crisis catapulted public health leadership at the forefront of the public arena. Lessons about how to handle this particular situation are relevant not only as a scrutiny of the actions taken but as a guide for managing the remaining consequences of COVID-19 as well as other similar future crises (Nyenswah et al., 2016).

The article draws on examples from three different countries, which help in presenting alternative perspectives under a single framework. We combine both elements to exploit the heterogeneity of the selected countries and, through the lens of Boin et al.'s crisis leadership framework, show common elements present in the crisis leadership of the COVID-19 situation, as well as idiosyncratic responses. Additionally, we provide a real-time analysis considering the crisis is still ongoing in all the countries - which is relevant not just to think about what could have been done differently but actually improve the response for the coming months.

\section{References}

Andrews, J.P. (2020), "Autoridades piden homenajear a los trabajadores de la salud con aplausos masivos hoy a las 21.00", La Tercera, Vol. 26 May, available at: https://www.latercera.com/ nacional/noticia/autoridades-piden-homenajear-a-los-trabajadores-de-la-salud-con-aplausosmasivos-hoy-a-las-2100/RGU2STIC35BUBPPD4ARAJISC24/ (accessed 27 August 2020).

Artus, P. (2020), "Le capitalisme néolibéral corrigé ou durci après la crise du coronavirus ?", Le Point, Vol. 8 May, available at: https://www.lepoint.fr/invites-du-point/patrick-artus/artus-lecapitalisme-neoliberal-corrige-ou-durci-apres-la-crise-du-coronavirus-08-05-2020-2374675_1448. php\# (accessed 24 August 2020).

Barlett, J. (2020), "Chile celebrated success against the coronavirus — and began to open up. Infections have soared", The Washington Post, Vol. 23 June, available at: https://www.washingtonpost. com/world/the_americas/chile-coronavirus-lockdown-sebastian-pinera/2020/06/23/70e9701ab4a7-11ea-aca5-ebb63d27e1ff_story.html\#click=https://t.co/iqRaa3F1Au (accessed 19 August 2020).

BBC (2020), "Coronavirus: chile to introduce controversial 'virus-free' certificates", 26 April, available at: https://www.bbc.com/news/world-latin-america-52436330 (accessed 19 August 2020).
Public health leadership in times of COVID 
IJPL

17,1

Bikales, J. (2020), Sens. Markey, Cruz Clash over Coronavirus Relief: 'It's Not a Goddamn Joke Ted', 10 August, The Hill, available at: https://thehill.com/homenews/senate/511350-markey-andcruz-clash-on-twitter-over-coronavirus-relief-its-not-a-goddamn (accessed 20 August 2020).

Boin, A. and 't Hart, P. (2003), "Leadership in times of crisis: mission impossible?", Public Administration Review, Vol. 63 No. 5, pp. 544-553.

Boin, A., 't Hart, P., Stern, E. and Sundelius, B. (2005), The Politics of Crisis Management: Public Leadership under Pressure, Cambridge University Press, Cambridge.

Bossert, T.J. and Villalobos Dintrans, P. (2020), "Health reform in the midst of a social and political crisis in Chile, 2019-2020", Health Systems and Reform, Vol. 6 No. 1, e1789031.

Brookes, S. (2011), "Crisis, confidence and collectivity: responding to the new public leadership challenge", Leadership, Vol. 7 No. 2, pp. 175-194.

Bump, P. (2020), "Yet again, Trump pledges that the coronavirus will simply go away", The Washington Post, Vol. 28 April, available at: https://www.washingtonpost.com/politics/2020/04/ 28/yet-again-trump-pledges-that-coronavirus-will-simply-go-away/ (accessed 20 August 2020).

Cerda, L. (2020), "Presidente Piñera: 'Chile está mucho mejor preparado que Italia para enfrentar esta situación”, La Tercera, Vol. 18 March, available at: https:/www.latercera.com/politica/noticia/ pinera-y-estado-de-catastrofe-podemos-confiscar-bienes-que-son-esenciales-para-las-personas-yponerlos-a-disposicion-de-la-gente/HUQGNFGE3NFPRII3LDS5IAHHWM/ (accessed 19 August 2020).

CNN-Chile (2020a), "Mañalich defiende cuarentenas dinámicas: 'Es la estrategia que han tomado la mayoría de los países en el mundo", 11 June, available at: https://www.cnnchile.com/pais/ manalich-defiende-estrategia-cuarentenas-dinamicas_20200611/ (accessed 19 August 2020).

CNN-Chile (2020b), "Senado aprueba proyecto de acuerdo para pedir un bono especial dirigido a trabajadores de la salud”, 15 April, available at: https://www.cnnchile.com/coronavirus/senadoproyecto-bono-trabajadores-salud_20200415/.

Conseil Scientifique COVID-19 (2020), “Avis du 14 mars 2020", available at: https://solidarites-sante. gouv.fr/IMG/pdf/avis_conseil_scientifique_14_mars_2020.pdf (accessed 15 September 2020).

Cooperativa (2020a), "Casos de coronavirus en Chile llegan a los 23 y Gobierno anuncia Consejo Asesor", 11 March, available at: https:/www.cooperativa.cl/noticias/sociedad/salud/gripes/ casos-de-coronavirus-en-chile-llegan-a-los-23-y-gobierno-anuncia-consejo/2020-03-11/123902. html (accessed 19 August 2020).

Cooperativa (2020b), "Encuesta: siete de cada diez chilenos no confían en la información del Gobierno sobre el Covid-19", 22 May, available at: https:/www.cooperativa.cl/noticias/sociedad/salud/ coronavirus/encuesta-siete-de-cada-diez-chilenos-no-confian-en-la-informacion-del/2020-05-22/ 233159.html (accessed 19 August 2020).

Crosby, B.C. and Bryson, J.M. (2018), "Why leadership of public leadership research matters: and what to do about it", Public Management Review, Vol. 20 No. 9, pp. 1265-1286.

Dautriche, L. (2020), "De l'aveuglement à l'urgence: retour sur cinq mois de crise du coronavirus en France", 9 May, available at: https://www.europe1.fr/societe/recit-de-laveuglement-a-lurgenceretour-sur-cinq-mois-de-crise-du-coronavirus-en-france-3967193 (accessed 24 August 2020).

Deitchman, S. (2013), "Enhancing crisis leadership in public health emergencies", Disaster Medicine and Public Health Preparedness, Vol. 7 No. 5, pp. 534-540.

Devine, D., Gaskell, J., Jennings, W. and Stoker, G. (2020), "Trust and the coronavirus pandemic: what are the consequences of and for trust?", An Early Review of the Literature. Political Studies Review.

Discover Magazine (2020), "The public health legacy of the 1976 swine flu outbreak", 30 September, available at: https://www.discovermagazine.com/health/the-public-health-legacy-of-the-1976swine-flu-outbreak (accessed 15 September 2020).

Elysee (2020), “Adresse aux Français du Président Emmanuel Macron du 12 Mars 2020", available at: https://www.elysee.fr/emmanuel-macron/2020/03/12/adresse-aux-francais (accessed 24 August 2020). 
Esquire (2020), “The renegade scientist behind hydroxychloroquine, donald trump's miracle coronavirus cure", 1 May, available at: https://www.esquire.com/uk/life/a32284282/hydroxy chloroquine-donald-trump-coronavirus-cure-didier-raoult/ (accessed 15 September 2020).

Fassin, P. (2020), "L'illusion dangeureuse de l'égalité devant l'épidemie", available at: https://www. college-de-france.fr/site/didier-fassin/L-illusion-dangereuse-de-legalite-devant-lepidemie.htm (accessed 24 August 2020).

Forbes (2020), "There's no tradeoff between targeting coronavirus and restarting the economy-they're intertwined", 26 March 2020, available at: https:/www.forbes.com/sites/joshuacohen/2020/03/ 26/tradeoff-between-public-health-measures-targeting-covid-19-and-the-economy-is-a-falsedichotomy/\#45eff888260d (accessed 26 August 2020).

France Info (2020), “Quoi qu'il en coûte' : emmanuel Macron lance un appel général à la mobilisation contre le coronavirus", 12 Mars, available at: https:/www.francetvinfo.fr/sante/maladie/ coronavirus/quoi-qu-il-en-coute-emmanuel-macron-lance-un-appel-general-a-la-mobilisationcontre-le-coronavirus_3863731.html (accessed 14 September 2020).

France Television (2020), "Ne commettez pas nos erreurs': le correspondant de France Télévisions à Rome relaie l'avertissement des Italiens face au coronavirus", 13 Mars, available at: https:// www.francetvinfo.fr/sante/maladie/coronavirus/coronavirus-1-italie-alerte-la-france_3865325. html (accessed 24 August 2020).

Getha-Taylor, H., Holmes, M.H., Jacobson, W.S., Morse, R.S. and Sowa, J.E. (2011), "Focusing the public leadership lens: research propositions and questions in the Minnowbrook tradition", Journal of Public Administration Research and Theory, Vol. 21 suppl_1, pp. i83-i97.

Gray, M. (2009), "Public health leadership: creating the culture for the twenty-first century", Journal of Public Health, Vol. 31 No. 2, pp. 208-209.

Hale, T., Angrist, N., Kira, B., Petherick, A., Phillips, T. and Webster, S. (2020), "Variation in government responses to COVID-19", Version 6.0, Blavatnik School of Government Working Paper, May 25, available at: www.bsg.ox.ac.uk/covidtracker (accessed 24 August 2020).

Hannah, S.T., Uhl-Bien, M., Avolio, B.J. and Cavarretta, F.L. (2009), "A framework for examining leadership in extreme contexts", The Leadership Quarterly, Vol. 20, pp. 897-919.

Johns Hopkins University (2020), "Mortality analyses”, available at: https://coronavirus.jhu.edu/data/ mortality (accessed 12 August 2020).

Jong, W. (2017), "Meaning making by public leaders in times of crisis: an assessment", Public Relations Review, Vol. 43, pp. 1025-1035.

Jung, K., Jae Moon, M. and Hahm, S.D. (2008), "Exploring the linkage between ministerial leadership and performance in Korea", Administration and Society, Vol. 40 No. 7, pp. 667-690.

Kapucu, N. and Van Wart, M. (2008), "Making matters worse: an anatomy of leadership failures in managing catastrophic events", Administration and Society, Vol. 40 No. 7, pp. 711-740.

Kirlin, J.J. (1996), "The big questions of public administration in a democracy", Public Administration Review, pp. 416-423.

La Tercera (2020), "Lavín anuncia que no autorizará apertura del mall Apumanque tras aumento de contagios en la RM", 1 May, available at: https://www.latercera.com/nacional/noticia/lavinanuncia-que-no-autorizara-apertura-de-apumanque-tras-aumento-de-contagios-en-la-rm/ 2VNJLPFSXZBNDG45RMBY7UHY6Y/ (accessed 19 August 2020).

Levi, M. and Stoker, L. (2000), "Political trust and trustworthiness", Annual Review of Political Science, Vol. 3 No. 1, pp. 475-507.

Levi, M., Sacks, A. and Tyler, T. (2009), "Conceptualizing legitimacy, measuring legitimating beliefs", American Behavioral Scientist, Vol. 53 No. 3, pp. 354-375.

Lijphart, A. (1971), "Comparative politics and the comparative method", American Political Science Review, Vol. 65 No. 3, pp. 683-693.

Maor, M. (2014), "Policy persistence, risk estimation and policy underreaction", Policy Sciences, Vol. 47 No. 4 , pp. $425-443$. 
IJPL 17,1

Ministere de l'Economie, des Finances et de la Relance (2020), "Coronavirus COVID-19 : les mesures de soutien aux entreprises", available at: https://www.economie.gouv.fr/covid19-soutienentreprises/les-mesures (accessed 15 September 2020).

Ministère des Affaires Etrangères (2020), "Communiqué de presse: initiative Franco-Allemande pour la relance europeenne face a la crise du coronavirus", 18 May, available at: https://www. diplomatie.gouv.fr/fr/le-ministere-et-son-reseau/actualites-du-ministere/informationscoronavirus-covid-19/coronavirus-declarations-et-communiques/article/initiative-francoallemande-pour-la-relance-europeenne-face-a-la-crise-du (accessed 25 August 2020).

Ministère des Solidarités et de la Santé (2020), “Communiqué de presse de Olivier Véran du”, 11 Mars 2020, available at: https://solidarites-sante.gouv.fr/actualites/presse/communiques-de-presse/ article/olivier-veran-installe-un-conseil-scientifique (accessed 24 August 2020).

Ministerio de Salud (2020), "Ministro de Salud es designado como Coordinador Interministerial del Plan de Coronavirus", 13 March, available at: https://www.minsal.cl/ministro-de-salud-esdesignado-como-coordinador-interministerial-del-plan-de-coronavirus/ (accessed 19 August 2020).

Moodie, R. (2016), "Learning about self: leadership skills for public health", Journal of Public Health Research, Vol. 5 No. 1, p. 679.

NBC News (2020), "Dan Patrick on coronavirus: 'More important things than living”, 21 April, available at: https://www.nbcnews.com/news/us-news/texas-lt-gov-dan-patrick-reopeningeconomy-more-important-things-n1188911 (accessed 20 August 2020).

New York Times (2020), "C.D.C. Changes testing guidance to exclude people without covid-19 symptoms, worrying experts", 25 August 2020, available at: https://www.nytimes.com/2020/08/ 25/world/covid-19-coronavirus.html (accessed 26 August 2020).

NPR (2020a), "COVID-19 hospital data system that bypasses CDC plagued by delays, inaccuracies", 31 July 2020, available at: https://www.npr.org/sections/health-shots/2020/07/31/897429054/ covid-19-hospital-data-system-that-bypasses-cdc-plagued-by-delays-inaccuracies (accessed 26 August 2020).

NPR (2020b), "Charts: how the U.S. Ranks on COVID-19 deaths per capita-and by case count", 5 August 2020, available at: https://www.npr.org/sections/goatsandsoda/2020/08/05/899365887/ charts-how-the-u-s-ranks-on-covid-19-deaths-per-capita-and-by-case-count (accessed 26 August 2020).

Nyenswah, T., Engineer, C.Y. and Peters, D.H. (2016), "Leadership in times of crisis: the example of EbolaVirus disease in Liberia”, Health Systems and Reform, Vol. 2 No. 3, pp. 194-207.

Ospina, S.M. (2017), "Collective leadership and context in public administration: bridging public leadership research and leadership studies", Public Administration Review, Vol. 77 No. 2, pp. 275-287.

O'Reilly, D., Leitch, C.M., Harrison, R.T. and Lamprou, E. (2015), "Introduction: leadership in a crisesconstructing world", Leadership, Vol. 11 No. 4, pp. 387-395.

Pew Research Center (2020), "Republicans, Democrats move even further apart in coronavirus concerns", 25 June 2020, available at: https://www.pewresearch.org/politics/2020/06/25/ republicans-democrats-move-even-further-apart-in-coronavirus-concerns/ (accessed 26 August 2020). 
Puska, P. (2007), "Health in all policies", The European Journal of Public Health, Vol. 17 No. 4, pp. 328-328.

Philippe, B. (2020), Les fameux avis scientifiques qui ont poussé au maintien du premier tour des municipales, 18 Mars 2020, available at: https:/www.capital.fr/economie-politique/les-fameuxavis-scientifiques-qui-ont-pousse-au-maintien-du-premier-tour-des-municipales-1365100 (accessed 15 September 2020).

Scientific American (2020), "Nine COVID-19 myths that just won't go away", 18 August 2020, available at: https://www.scientificamerican.com/article/nine-covid-19-myths-that-just-wont-goaway/ (accessed 26 August 2020).

Sepúlveda, N. (2020), "Minsal reporta a la OMS una cifra de fallecidos más alta que la informada a diario en Chile", Ciper-Chile, Vol. 13 June, available at: https:/ciperchile.cl/2020/06/13/minsalreporta-a-la-oms-una-cifra-de-fallecidos-mas-alta-que-la-informada-a-diario-en-chile/ (accessed 19 August 2020).

Siegrist, M. and Zingg, A. (2014), "The role of public trust during pandemics: implications for crisis communication”, European Psychologist, Vol. 19 No. 1, p. 23.

Slate (2020), "The trump pandemic: a blow-by-blow account of how the president killed thousands of Americans", 9 August, available at: https:/slate.com/news-and-politics/2020/08/trumpcoronavirus-deaths-timeline.html (accessed 20 August 2020).

Telo, L. (2020), "Mauvais timing, mauvais casting, mauvaises raisons. . . les medailles de la discorde", Le Monde, Vol. 24 Mai, available at: https:/www.lemonde.fr/m-le-mag/article/2020/05/24/ mauvais-timing-mauvais-casting-mauvaises-raisons-les-medailles-de-la-discorde_6040586_ 4500055.html (accessed 27 August 2020).

The Atlantic (2020), "How the pandemic defeated America", 4 August, available at: https://www. theatlantic.com/magazine/archive/2020/09/coronavirus-american-failure/614191/ (accessed 20 August 2020).

The Conversation (2020), "Is the COVID-19 pandemic cure really worse than the disease? Here's what our research found", 7 July 2020, available at: https://theconversation.com/is-the-covid-19pandemic-cure-really-worse-than-the-disease-heres-what-our-research-found-141700 (accessed 26 August 2020).

The Lancet Infectious Diseases, Editorial (2020), "The COVID-19 infodemic", The Lancet Infectious Diseases, Vol. 20 No. 8, p. 875.

The Nation (2020), "6 ways Trump is exploiting this pandemic for political gain", 8 April 2020, available at: https://www.thenation.com/article/politics/coronavirus-trump-immigrationelection/ (accessed 26 August 2020).

The Washington Post (2020a), “Trump's bizarre effort to tag Obama's swine flu response as 'a disaster", 21 April, available at: https://www.washingtonpost.com/politics/2020/04/21/ trumps-bizarre-effort-tag-obamas-swine-flu-response-disaster/ (accessed 15 September 2020).

The Washington Post (2020b), "Democratic lawmakers probing whether CDC guidelines on reopening schools were influenced by political pressure", 28 July 2020, available at: https://www. washingtonpost.com/education/2020/07/28/democratic-lawmakers-probing-whether-cdcguidelines-reopening-schools-were-influenced-by-political-pressure/ (accessed 26 August 2020).

Tilley, N. (2010), “Can public leadership be evaluated?”, The New Public Leadership Challenge, Palgrave Macmillan, London, pp. 325-340.

Van Bavel, J.J., Baicker, K., Boggio, P.S., Capraro, V., Cichocka, A., Cikara, M., Crockett, M.J., Crum, A.J., Douglas, K.M., Druckman, J.N., Drury, J., Dube, O., Ellemers, N., Finkel, E.J., Fowler, J.H., Gelfand, M., Han, S., Haslam, S.A., Jetten, J., Kitayama, S., Mobbs, D., Napper, L.E., Packer, D.J., Pennycook, G., Peters, E., Petty, R.E., Rand, D.G., Reicher, S.D., Schnall, S., Shariff, A., Skitka, L.J., Smith, S.S., Sunstein, C.R., Tabri, N., Tucker, J.A., van der Linden, S., van Lange, P., Weeden, K.A., Wohl, M.J.A., Zaki, J., Zion, S.R. and Willer, R. (2020), "Using social and behavioural science to support COVID-19 pandemic response", Nature Human Behaviour, Vol. 4 No. 5, pp. 460-471. 
IJPL

17,1

94

Van Wart, M. (2013), "Administrative leadership theory: a reassessment after 10 years", Public Administration, Vol. 91 No. 3, pp. 521-543.

Villalobos Dintrans, P., Browne, J. and Madero-Cabib, I. (2020), "It is not just mortality: a call from Chile for comprehensive COVID-19 policy responses among older people", The Journals of Gerontology Series B: Psychological Sciences and Social Sciences, Published online 2020 Jul 7. doi: 10.1093/geronb/gbaa092.

Vogel, R. and Masal, D. (2015), "Public leadership: a review of the literature and framework for future research”, Public Management Review, Vol. 17 No. 8, pp. 1165-1189, 2015.

Vogel, D., Reuber, A. and Vogel, R. (2020), Developing a Short Scale to Assess Public Leadership, Public Administration, Published online 2020 Mar 19. doi: 10.1111/padm.12665.

World Health Organization (2020a), "Rolling updates on coronavirus disease (COVID-19)", available at: https://www.who.int/emergencies/diseases/novel-coronavirus-2019/events-as-they-happen (accessed 12 August 2020).

World Health Organization (2020b), "Coronavirus disease pandemic”, available at: https://www.who. int/emergencies/diseases/novel-coronavirus-2019 (accessed 16 September 2020).

Yahoo News (2020), “Trump: 'I disagree' with Fauci on COVID-19 in the US”, 7 July, available at: https://news.yahoo.com/trump-disagree-fauci-covid-19-us-000301814.html (accessed 20 August 2020).

Yin, R.K. (2014), Case Study Research: Design and Methods, 5th ed., Sage, Thousand Oaks, CA.

Yphantides, N., Escoboza, S. and Macchione, N. (2015), "Leadership in public health: new competencies for the future", Frontiers in Public Health, Vol. 3, p. 24.

\section{Corresponding author}

Pablo Villalobos Dintrans can be contacted at: pvillalobos.d@gmail.com

For instructions on how to order reprints of this article, please visit our website:

www.emeraldgrouppublishing.com/licensing/reprints.htm

Or contact us for further details: permissions@emeraldinsight.com 